\title{
Relative Salt Tolerance of Eight Japanese Barberry Cultivars
}

\author{
Lifei Chen ${ }^{1}$
}

Jilin Agricultural University, 2888 Xincheng Street, Changchun, Jilin 130118, China; and Texas A\&M AgriLife Research Center at El Paso, Texas A\&M University System, 1380 A\&M Circle, El Paso, TX 79927

\author{
Youping Sun ${ }^{1,2}$ \\ Department of Plants, Soils and Climate, Utah State University, 4820 Old \\ Main Hill, Logan, UT 84322
}

Genhua Niu ${ }^{1,2}$ and Qiang Liu

Central South University of Forestry and Technology, 498 S. Shaoshan Road, Changsha, Hunan 410004, China; and Texas A\&M AgriLife Research Center at El Paso, Texas A\&M University System, 1380 A\&M Circle, El Paso, TX 79927

\section{James Altland USDA-ARS, 1680 Madison Avenue, Wooster, OH 44691}

Additional index words. Berberis thunbergii, gas exchange, mineral nutrition, salinity

Abstract. Relative salt tolerance of eight Berberis thunbergii (japanese barberry) cultivars (B. thunbergii 'Celeste', 'Kasia', 'Maria', 'Mini', and 'Talago'; B. thunbergii var. atropurpurea 'Concorde', 'Helmond Pillar', and 'Rose Glow') was evaluated in a greenhouse experiment. Plants were irrigated with nutrient solution at an electrical conductivity (EC) of $1.2 \mathrm{dS} \cdot \mathrm{m}^{-1}$ (control) or saline solutions at an EC of 5.0 or 10.0 $\mathrm{dS} \cdot \mathrm{m}^{-1}$ (EC 5 or EC 10) once a week for 8 weeks. At 4 weeks after treatment, all barberry cultivars in EC 5 had minimal foliar damage with visual scores of 4 or greater (visual score 0: dead, 5: excellent). At 8 weeks after treatment, in EC 5, 'Helmond Pillar', 'Maria', 'Mini', and 'Rose Glow' plants exhibited slight foliar salt damage with an average visual score of 3.5, whereas 'Celeste', 'Concorde', 'Kasia', and 'Talago' had minimal foliar salt damage with an averaged visual score of 4.4. However, most barberry plants in EC 10 exhibited severe foliar salt damage 4 weeks after treatment with the exception of 'Concorde' and were dead 8 weeks after treatment. Compared with control, at the end of the experiment (8 weeks of treatments), shoot dry weight (DW) of 'Celeste', 'Helmond Pillar', 'Maria', and 'Rose Glow' in EC 5 was reduced by $47 \%, 47 \%, 50 \%$, and $42 \%$, respectively, whereas shoot DW of 'Concorde', 'Kasia', 'Mini', and 'Talago' in EC 5 did not change. In EC 10, shoot DW of 'Celeste', 'Concorde', 'Kasia', and 'Talago' was reduced by $75 \%, 35 \%, 55 \%$, and $46 \%$, respectively. The averaged sodium $(\mathrm{Na})$ concentration of all barberry cultivars in EC 5 and EC 10 was 34 and 87 times, respectively, higher than the control, whereas leaf chloride $(\mathrm{CI})$ concentration of all barberry cultivars in EC 5 and EC 10 was 14-60 and 29-106 times, respectively, higher than the control. Growth, visual quality, and performance index (PI) were all negatively correlated with leaf $\mathrm{Na}$ and $\mathrm{Cl}$ content in all cultivars, suggesting that excessive $\mathrm{Na}$ and $\mathrm{Cl}$ accumulation in the leaf tissue led to growth reduction, salt damage, and death. In summary, 'Concorde', 'Kasia', and 'Talago' were relatively salt tolerant; 'Helmond Pillar', 'Maria', 'Mini', and 'Rose Glow' were relatively salt sensitive; and 'Celeste' was in between the two groups. Generally, barberry plants had moderate salt tolerance and can be irrigated with marginal water at an EC of $5 \mathrm{dS} \cdot \mathrm{m}^{-1}$ or lower with slight foliar damage.

Water and soil salinization are global problems and are more severe in waterscarce areas such as arid and semiarid regions, where groundwater is the primary source of water. The increasing population has intensified the competition for highquality water supply among urban and agricultural water users. Therefore, using alternative water sources such as municipal reclaimed water to irrigate nursery crops and landscape plants has drawn considerable attention (Grieve, 2011). Reclaimed water carries relatively high levels of soluble salts, which negatively affect plant growth and development and impose foliar salt injury on sensitive plants (Niu and Cabrera, 2010; Veatch-Blohm et al., 2014). The salinity of groundwater, which is a primary water source for nursery crops in some areas, varies with location and rainfall (Niu and Cabrera, 2010). Overuse of groundwater leads to decline of water table and increases salinity (Smith et al., 2016). Therefore, information on salt tolerance of nursery and landscape crops is necessary to prevent salt damage and maintain aesthetically appealing landscapes.

Berberis thunbergii (japanese barberry) is a species native to Japan and eastern Asia, although widely naturalized in China and North America (Wikipedia, The Free Encyclopedia, 2017). It is a multibranched dense shrub that can grow up to $2.5 \mathrm{~m}$ tall with shiny green to burgundy alternate leaves along its thorny stems (Dirr, 1998). It has solitary yellow flowers that bloom from March to April and produces round or elliptical red berries (Dirr, 1998). Japanese barberry is a widely grown landscape plant that was awarded the prestigious Royal Horticultural Societies Annual Award of Garden Merit in 1993 (Davis Landscape Architecture, 2017). In the United States, an estimated $\$ 30$ million in barberry plants are sold annually (U.S. Department of Agriculture, 2009). Previous breeding efforts have led to numerous cultivars that offer different foliage colors (yellow, dark red to violet, or variegated foliage) and forms (erect growth or dwarf size) (Dirr, 1998). For example, $B$. thunbergii var. atropurpurea 'Concorde' is extremely slow growing with a compact habit and small deep red or purple leaves that hold color in heat (Dirr, 1998). Berberis thunbergii var. atropurpurea 'Helmond Pillar' is a distinct upright with fastigiate form and reddish purple leaves that usually grows up to $1.5 \mathrm{~m}$ tall and $0.6 \mathrm{~m}$ wide forming a slowgrowing column (Dirr, 1998). Berberis thunbergii var. atropurpurea 'Rose Glow' can grow about $1.5-1.8 \mathrm{~m}$ tall and produces new foliage in rose-pink mottled with deeper redpurple splotches that gradually mature to a deep reddish purple (Dirr, 1998).

Salt tolerance of barberry species has been reported in extension articles. For example, Beckerman and Lerner (2009) reported that Berberis species are sensitive or have intermediate tolerance to aerial salt spray, whereas they are sensitive to soil salinity. On the list of salt-tolerant plants compiled by Chalet Nursery (2013), Berberis species have high aerial salt tolerance and low soil salt tolerance. Berberis thunbergii has poor soil salt tolerance (Gilman, 2014) and high tolerance to aerial salt spray (Jull, 2009). Berberis koreana also has high tolerance to aerial salt spray (Jull, 2009), but its tolerance to soil salinity is yet to be determined. Berberis julianae and Berberis bealei have moderate salt tolerance (Glen et al., 2004; Harrison, 2009). However, these reports are mostly based on anecdotal observations without defined thresholds for categories of salt tolerance. Only a few research-based studies have been conducted to evaluate the responses of barberry plants to salinity. Monk and Wiebe (1961) reported that $B$. thunbergii was not salt tolerant based on the study in salinized field plots. Berberis thunbergii is listed as a very salt-sensitive plant because a $25 \%$ growth reduction occurred when the EC of a saturation extract of growing medium was $1.8 \mathrm{dS} \cdot \mathrm{m}^{-1}$, whereas Berberis $\times$ mentorensis is listed as a salt-sensitive plant tolerating a saturation extract of EC up to 3-4 dS.m ${ }^{-1}$ (Costello et al., 
2003; Handreck and Black, 2002). Two-yearold seedlings of $B$. thunbergii 'Atropurpurea' showed no significant difference in annual growth when irrigated with tap water, tap water containing $3.3 \mathrm{~g} \cdot \mathrm{L}^{-1} \mathrm{NaCl}, 6.0 \mathrm{~g} \cdot \mathrm{L}^{-1}$ $\mathrm{CaCl}_{2}$, or $10.5 \mathrm{~g} \cdot \mathrm{L}^{-1} \mathrm{Na}_{2} \mathrm{CO}_{3}$ for eight times at 7-d intervals (Marosz, 2012).

Given that salt tolerance varies considerably among species and even cultivars within a species, a systematic study is needed to investigate the salt tolerance of different barberry cultivars. The objectives of this study were to evaluate the relative salt tolerance of eight barberry cultivars in a greenhouse study using the parameters of shoot growth, visual quality, chlorophyll content, PI, and mineral concentration in response to elevated salinity of irrigation solution.

\section{Materials and Methods}

Plant materials and growing conditions. Rooted cuttings $(\approx 6 \mathrm{~cm})$ of barberry cultivars $\left[\right.$ B. thunbergii 'Celeste' (Sunjoy ${ }^{\circledR}$ Cinnamon), 'Kasia' (Sunjoy ${ }^{\circledR}$ Mini Saffron), 'Maria' (Sunjoy ${ }^{\circledR}$ Gold Pillar), 'Mini' (Sunjoy ${ }^{\circledR}$ Mini Salsa), and 'Talago' (Sunjoy ${ }^{\circledR}$ Gold Beret); B. thunbergii var. atropurpurea 'Concorde', 'Helmond Pillar', and 'Rose Glow'] were received from Spring Meadow Nursery Inc. on 3 Mar. 2016. On 8 Mar., the cuttings were transplanted into 2.7 -L black polyethylene injection-molded containers (C-650; Lerio Corp., Mobile, AL) containing MetroMix 360 RSI [canadian sphagnum peatmoss $45 \%$ to $55 \%$, vermiculite, composed bark, dolomite limestone, $0.0001 \%$ silicon dioxide $\left(\mathrm{SiO}_{2}\right)$; SunGro Hort., Bellevue, WA]. All barberry plants were placed in a greenhouse in El Paso, TX (lat. $31^{\circ} 41^{\prime} 45^{\prime \prime} \mathrm{N}$, long. $106^{\circ} 16^{\prime} 54^{\prime \prime} \mathrm{W}$, elev. $\left.1139 \mathrm{~m}\right)$. They were irrigated to saturation initially and then watered as needed afterward with reverse osmosis (RO) water-based nutrient solution

\footnotetext{
Received for publication 1 Aug. 2017. Accepted for publication 20 Oct. 2017.

This research is supported by a Specific Cooperative Agreement from the United States Department of Agriculture (USDA), Agricultural Research Service, the USDA National Institute of Food and Agriculture Hatch project TEX090450, and Texas A\&M AgriLife Research. The content is solely the responsibility of the authors and does not necessarily represent the official views of the funding agencies. Mention of a trademark, proprietary product, or vendor does not constitute a guarantee or warranty of the product by USDA and does not imply its approval to the exclusion of other products or vendors that also may be suitable. The authors appreciate the financial support from China Scholarship Council to Qiang Liu as a visiting graduate student and Lifei Chen as a visiting scholar at Texas A\&M AgriLife Research Center at El Paso, TX, and the in-kind support of plant materials from Spring Meadow Nursery Inc. (Grand Haven, MI).

We thank Douglas Sturtz at USDA-ARS for his help in mineral analysis.

${ }^{1}$ These authors contributed equally.

${ }^{2}$ Corresponding authors. E-mail: youping.sun@ usu.edu orgniu@ag.tamu.edu.
}

to avoid salt accumulation in the root zone until treatments started. Three weeks after transplanting (i.e., 29 Mar.), uniform plants were chosen for salt tolerance screening, and treatments were started. The average air temperature in the greenhouse was $26.7 \pm$ $4.1^{\circ} \mathrm{C}$ (mean and SD) during the day and $18.1 \pm$ $4.6{ }^{\circ} \mathrm{C}$ at night. The average daily light integral was $9.6 \pm 1.5 \mathrm{~mol} \cdot \mathrm{m}^{-2} \cdot \mathrm{d}^{-1}$ and the average relative humidity was $35.6 \% \pm$ $12.9 \%$ during the experiment period.

Treatments. A nutrient solution at an EC of $1.2 \pm 0.1 \mathrm{dS} \cdot \mathrm{m}^{-1}$ was used as the control. The nutrient solution was prepared by adding $1 \mathrm{~g} \cdot \mathrm{L}^{-1} 15 \mathrm{~N}-2.2 \mathrm{P}-12.5 \mathrm{~K}$ (Peters $15-5-15 \mathrm{Ca}-$ $\mathrm{Mg}$ Special; Scotts, Marysville, $\mathrm{OH}$ ) to $\mathrm{RO}$ water. Saline solutions at an EC of $5.0 \pm 0.1$ $\mathrm{dS} \cdot \mathrm{m}^{-1}$ (EC 5) and $10.0 \pm 0.1 \mathrm{dS} \cdot \mathrm{m}^{-1}$ (EC 10) were prepared by adding $20.6 \mathrm{~mm}$ sodium chloride $(\mathrm{NaCl})$ and $10.4 \mathrm{~mm}$ calcium chloride $\left(\mathrm{CaCl}_{2}\right)$, and $47.8 \mathrm{~mm} \mathrm{NaCl}$ and $24.0 \mathrm{~mm}$ $\mathrm{CaCl}_{2}$, respectively, to the nutrient solution mentioned previously. The $\mathrm{pH}$ of all solutions was adjusted to 6.6-6.8 using potassium hydroxide. Both nutrient and saline solutions were prepared in 100-L tanks with confirmed EC using an EC meter (Model B173; Horiba, Ltd., Kyoto, Japan) before irrigation.

From 29 Mar. to 26 Apr., barberry plants were irrigated weekly with treatment solutions, $1 \mathrm{~L} /$ plant, resulting in a leaching fraction of $\approx 38 \%$. In addition, plants were irrigated with nutrient solution whenever substrate surface became dry between treatments. The irrigation frequency depended on environmental conditions, plant size, and treatments. For example, plants in the control often use more water and need to be irrigated more frequently than those at high salinity levels. On 10 May, five plants were harvested per treatment per cultivar (first harvest). From 13 May to 3 June, treatment solutions were applied weekly to the remaining barberry plants as described previously. On 13 June, all remaining five plants in each treatment were harvested (second harvest).

Leachate EC. The leachate EC was measured using the pour-thru technique as described by Cavins et al. (2008) and Wright (1986). One plant per treatment per cultivar was randomly selected for measurement after irrigating with treatment solution and EC readings were pooled across cultivars.

Visual quality and growth data. At harvest time, salt damage was rated by giving a visual score based on a reference scale from 0 to 5 , where $0=$ dead; $1=$ more than $90 \%$ foliar damage (salt damage: burning, necrosis, and discoloration); $2=$ moderate $(50 \%$ to $90 \%$ ) foliar damage; $3=$ slight (less than $50 \%$ ) foliar damage; $4=$ good quality with minimal foliar damage; and $5=$ excellent with no foliar damage (Sun et al., 2015b). The foliar salt damage rating did not consider plant size. Shoots were severed at the substrate surface, and leaf area was determined using an LI-3100C area meter (LI-COR ${ }^{\circledR}$ Biosciences, Lincoln, NE). Shoot DW was determined after oven-drying at $70{ }^{\circ} \mathrm{C}$ for $4 \mathrm{~d}$.

Leaf relative chlorophyll content. Relative chlorophyll content [soil plant analysis development (SPAD) reading] was recorded using a handheld chlorophyll meter (measured as the optical density; Minolta Camera Co., Osaka, Japan) on 4 May and 7 June. Healthy and fully expanded leaves in the middle of shoots were chosen for measurement, and five plants per treatment per cultivar were measured.

Performance index. The PI (Strasser et al., 2000, 2004) was measured at 1000 and $1400 \mathrm{HR}$ using a Hansatech Pocket PEA chlorophyll fluorimeter (Hansatech Instruments Ltd., Norfolk, UK) to examine the effect of elevated salinity on leaf photosynthetic apparatus of barberry plants at $36 \mathrm{~d}$ of treatment (i.e., 4 May) and $70 \mathrm{~d}$ of treatment (i.e., 7 June). Healthy and fully expanded leaves in the middle of shoots were chosen for measurement, and five plants per treatment per cultivar were measured. The leaves were dark adapted for at least $30 \mathrm{~min}$ before the measurements. Performance index was calculated as follows (Strasser et al., 2000; Živčák et al., 2008): $\mathrm{PI}=\frac{1-\left(F_{0} / F_{\mathrm{M}}\right)}{M_{0} / V_{J}} \times \frac{F_{\mathrm{M}}-F_{0}}{F_{0}} \times \frac{1-V_{J}}{V_{J}}$, where minimal fluorescence values in the dark-adapted state $\left(F_{0}\right)$ were obtained by application of a low-intensity red light-emitting diode light source $(627 \mathrm{~nm})$ at $50 \mu \mathrm{s}$, whereas maximal fluorescence values $\left(F_{\mathrm{M}}\right)$ were measured after applying a saturating light pulse of $3500 \mu \mathrm{mol} \cdot \mathrm{m}^{-2} \cdot \mathrm{s}^{-1}$. The parameter $F_{J}$ is the fluorescence intensity at the $J$ step at $2 \mathrm{~ms}$ and $V_{J}$ is the relative variable fluorescence at $2 \mathrm{~ms}$ calculated as $V_{J}=\left(F_{J}-F_{0}\right) /\left(F_{\mathrm{M}}-F_{0}\right), M_{0}$ represents the initial slope of fluorescence kinetics, which can be derived from the equation:

$$
M_{0}=4 \times\left(F_{300 \mu \mathrm{s}}-F_{0}\right) /\left(F_{\mathrm{M}}-F_{0}\right) .
$$

Mineral analysis. Shoot $\mathrm{Na}, \mathrm{Cl}, \mathrm{Ca}$, and potassium $(\mathrm{K})$ concentrations were analyzed using the dried materials from the first harvest with four samples per treatment per cultivar. Mineral analysis was not conducted for those samples from the second harvest because most plants in EC 10 did not survive. Dried tissue was ground to pass a 40-mesh screen with a stainless Wiley mill (Thomas Scientific, Swedesboro, NJ). The dried tissue samples were extracted with $2 \%$ acetic acid (Fisher Scientific, Fair Lawn, NJ) to determine $\mathrm{Cl}$ using the method described in Gavlak et al. (1994). The concentration of $\mathrm{Cl}$ was determined using a M926 Chloride Analyzer (Cole Parmer Instrument Company, Vernon Hills, IL). The dried tissue samples were submitted to the USDA-ARS (Toledo, $\mathrm{OH}$ ) for analyses of foliar $\mathrm{Na}, \mathrm{Ca}$, and $\mathrm{K}$. In brief, the dried tissue samples were digested in nitric acid following the protocol described by Havlin and Soltanpour (1989). Sodium, $\mathrm{Ca}$, and $\mathrm{K}$ in digested samples were analyzed using inductively coupled plasmaoptical emission spectrometer (iCAP 6300 Duo View ICP-OES; Thermo Fisher Scientific, Waltham, MA) and reported on a dry plant basis as described by Isaac and Johnson (1975). 
Experimental design and statistical analysis. The experiment used a split-plot design with the salinity treatment as the main plot and eight cultivars as the subplot with 10 replications per treatment per cultivar. Because of different plant growth habits, a oneway analysis of variance was performed separately for each cultivar. Means separation among treatments was conducted using Tukey's honestly significant difference multiple comparison at $\alpha=0.05$. When plants in EC 10 treatment were dead, mean comparison between control and EC 5 was analyzed by Student's $t$ test.

Relative shoot DW was calculated for each plant in EC 5 or EC 10 treatment as follows: relative shoot DW $(\%)=$ shoot DW in salt treatment/shoot DW in control $x$ $100 \%$. Similarly, relative values for leaf area and SPAD were calculated. These relative values and visual scores were used as salt tolerance indices for hierarchical cluster analysis (Zeng et al., 2002). The dendrogram and clustering of the eight barberry cultivars was obtained based on the Ward's linkage method and squared Euclidean distance on the means of the salt tolerance indices for four multivariate parameters including all relative values and visual scores. All statistical analyses were performed using JMP (Version 12; SAS Institute Inc., Cary, NC).

\section{Results and Discussion}

Leachate EC. Average leachate EC from 29 Mar. to 26 Apr. ranged from 2.5 to 3.1 $\mathrm{dS} \cdot \mathrm{m}^{-1}$ for control, 4.7 to $8.4 \mathrm{dS} \cdot \mathrm{m}^{-1}$ for EC 5 , and 6.5 to $14.8 \mathrm{dS} \cdot \mathrm{m}^{-1}$ for EC 10 (Fig. 1). From 13 May to 3 June, the average leachate EC of the control was $3.2-3.8 \mathrm{dS} \cdot \mathrm{m}^{-1}$, whereas that in EC 5 and EC 10 increased from 9.8 to $9.9 \mathrm{dS} \cdot \mathrm{m}^{-1}$ and from 15.5 to 17.3 $\mathrm{dS} \cdot \mathrm{m}^{-1}$, respectively. The higher EC values of leachate indicated salt accumulation in the substrate.

Visual quality. At the first harvest, all barberry plants in EC 5 had minimal foliar damage with visual scores of 4 or greater, whereas the visual scores of 'Helmond Pillar' and 'Mini' barberry were significantly reduced in EC 5 (Table 1). Treatment EC 10 reduced the visual quality of 'Concorde' barberry, but the visual score was still greater than 4. 'Celeste', 'Helmond Pillar', 'Kasia', 'Rose Glow', and 'Talago' in EC 10 had moderate foliar damage with visual scores of 2 to 3. 'Maria' and 'Mini' in EC 10 were severely damaged with visual scores near 1 . At the second harvest, 'Celeste', 'Concorde', 'Kasia', and 'Talago' were still in good quality with visual scores of 4 or greater in EC 5, whereas in EC 10, plants exhibited severe foliar salt damage with an averaged visual score of 0.9. 'Helmond Pillar', 'Maria', 'Mini', and 'Rose Glow' in EC 5 had slight foliar salt damage with averaged visual scores of 3.5, but all were dead in EC 10. These results indicated that the degree of the foliar damage in response to salinity is cultivar dependent.

Visual quality is an important parameter for ornamental plants and, therefore, visual

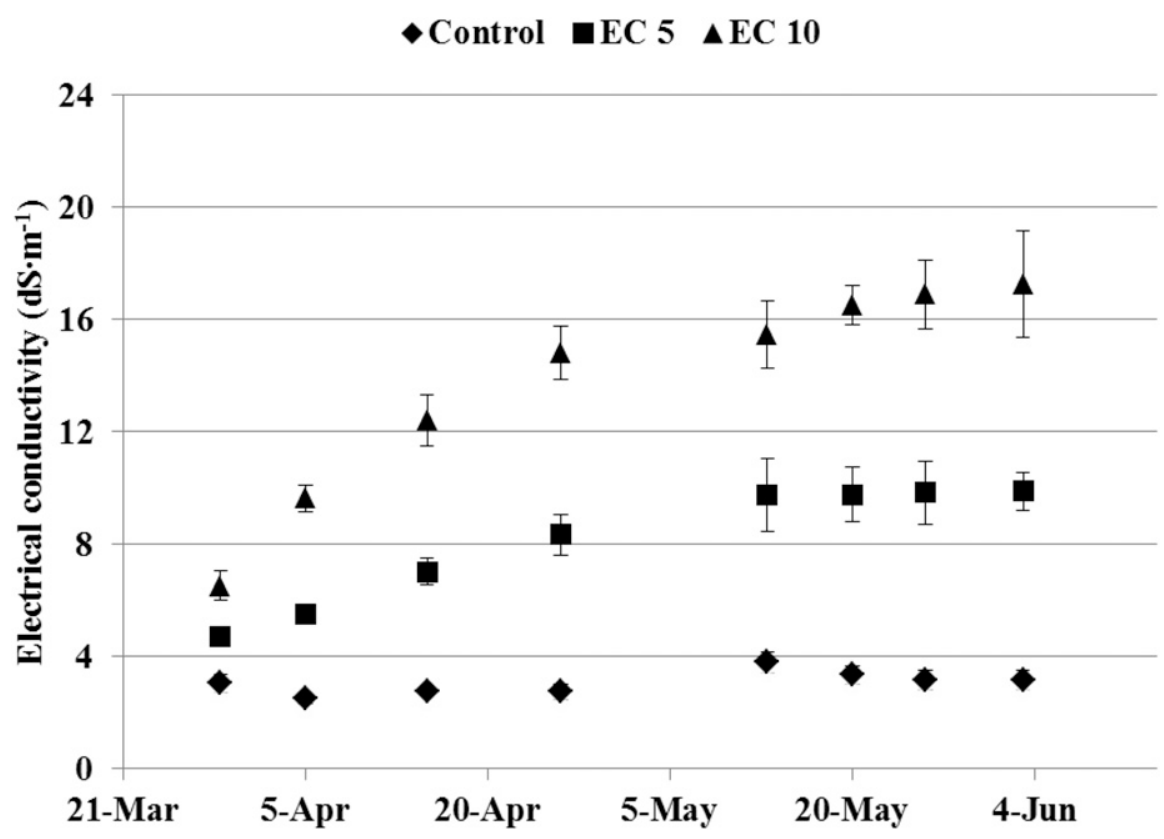

Fig. 1. Time course of weekly leachate electrical conductivity (EC) during the experimental period. Control represents nutrient solution at an EC of $1.2 \mathrm{dS} \cdot \mathrm{m}^{-1} ; \mathrm{EC} 5$ represents saline solution at an EC of $5.0 \mathrm{dS} \cdot \mathrm{m}^{-1}$ and EC 10 represents saline solution at an EC of $10.0 \mathrm{dS} \cdot \mathrm{m}^{-1}$. Vertical bars represent SE of eight samples, one sample per cultivar.

rating is always used as an important parameter in assessing salt tolerance of ornamental plants (Niu and Cabrera, 2010). Salinity may cause undesirable effects such as necrosis and leaf edge burn on ornamental plants that result in poor visual quality and eventually affect the marketability of ornamental plants (Wahome et al., 2001). As indicated by many researchers (Grieve et al., 2008; Niu and Cabrera, 2010), at elevated salinity conditions, salt-tolerant species, genotypes, or cultivars usually have less foliar salt injury compared with less salt-tolerant species. Based on this criterion, most of the tested cultivars of barberry were tolerant to an EC of $5.0 \mathrm{dS} \cdot \mathrm{m}^{-1}$ of irrigation water with acceptable visual quality (greater than 4.0), provided that well-drained substrate or soils are used to reduce salt accumulation in the root zone. The substrate used in this study resulted in salt accumulation (Fig. 1) which could have been caused by the high portion of peatmoss $(45 \%$ to $55 \%)$. Peatmoss has higher cation exchange capacity than pine bark (Altland et al., 2014), and thus may have retained higher salt levels than typical nursery substrates composed primarily of bark. Peatmoss also retains more water than bark with higher container capacity (Gabriel et al., 2009), and thus would drain less than typical substrates composed primarily of bark. To prevent salt accumulation, a substrate with lower peatmoss ratio should be used for long-term production.

Growth and relative chlorophyll content (SPAD). All barberry cultivars in EC 5 had similar leaf area to those in control at the first harvest (Table 1). Compared with control, in EC 10, 'Concorde', 'Helmond Pillar', and 'Talago' also had similar leaf area; however, 'Celeste', 'Kasia', 'Mini', and 'Rose Glow' had smaller leaf area. At the second harvest, reduced leaf area was observed on all barberry cultivars in EC 5 with exception of 'Concorde', 'Kasia', and 'Talago'. Salinity affected the growth of barberry as indicated by reduced shoot DW (Table 2). At the first harvest, in EC 5, only 'Celeste' and 'Maria' had decreased shoot DW. Treatment EC 10 further reduced the shoot DW of all barberry cultivars except Concorde, Helmond Pillar, and Talago. At the second harvest, shoot DW of 'Celeste', 'Helmond Pillar', 'Maria', and 'Rose Glow' in EC 5 was reduced, and that of 'Celeste', 'Concorde', 'Kasia', and 'Talago' in EC 10 was further reduced. These results suggest that barberry cultivars responded differently to elevated salinity, and 'Concorde', 'Kasia', and 'Talago' were more tolerant than the other cultivars. Elevated salinity has been previously reported to reduce the shoot and leaf biomass in a variety of plant species (Cai et al., 2014; Niu and Rodriguez, 2006; Niu et al., 2012a, 2012b, 2013; Sun et al., 2013, 2015a, 2015b).

Salinity negatively affected SPAD readings at both harvests (Table 2 ) with variations among cultivars. At the first harvest, saline solutions at EC 5 did not affect SPAD readings of all barberry cultivars with the exception of 'Celeste' and 'Maria' (Table 2). In EC 10, compared with control, reduced SPAD readings were observed on all barberry cultivars except Kasia. At the second harvest, elevated salinity reduced the SPAD readings of all barberry cultivars.

Based on the visual score and the reduction of shoot DW, 'Helmond Pillar', 'Maria', 'Mini', and 'Rose Glow' could be classified as salt sensitive, whereas 'Concorde', 'Kasia', and 'Talago' were more salt tolerant. 'Celeste' was in between the two groups. These conclusions were further 
Table 1. Visual score and leaf area of eight barberry cultivars irrigated with nutrient solution [electrical conductivity $(\mathrm{EC})=1.2 \mathrm{dS} \cdot \mathrm{m}^{-1} ; \mathrm{control}$ ) or saline solution $\left[E C=5.0 \mathrm{dS} \cdot \mathrm{m}^{-1}\right.$ (EC 5) or $10.0 \mathrm{dS} \cdot \mathrm{m}^{-1}$ (EC 10)] in the greenhouse. Plants were harvested after the fourth (first harvest) and eighth treatment (second harvest).

\begin{tabular}{|c|c|c|c|c|c|c|c|c|c|c|c|c|}
\hline \multirow{2}{*}{ Cultivars } & \multicolumn{6}{|c|}{ Visual score } & \multicolumn{6}{|c|}{ Leaf area $\left(\mathrm{cm}^{2}\right)$} \\
\hline & \multicolumn{3}{|c|}{ First harvest } & \multicolumn{3}{|c|}{ Second harvest } & \multicolumn{3}{|c|}{ First harvest } & \multicolumn{3}{|c|}{ Second harvest } \\
\hline Celeste & $5.0 \mathrm{a}^{\mathrm{z}}$ & $4.7 \mathrm{a}$ & $2.9 \mathrm{~b}$ & $5.0 \mathrm{a}$ & $4.0 \mathrm{a}$ & $0.6 \mathrm{~b}$ & $637 \mathrm{a}$ & $571 \mathrm{a}$ & $239 \mathrm{~b}$ & $1121 \mathrm{a}$ & $358 \mathrm{~b}$ & $-^{y}$ \\
\hline Helmond Pillar & $5.0 \mathrm{a}$ & $4.1 \mathrm{~b}$ & $2.0 \mathrm{c}$ & $5.0 \mathrm{a}$ & $3.4 \mathrm{~b}$ & $0.0 \mathrm{c}$ & $453 \mathrm{a}$ & $532 \mathrm{a}$ & $294 \mathrm{a}$ & $557 \mathrm{a}$ & $191 \mathrm{~b}$ & - \\
\hline Kasia & $5.0 \mathrm{a}$ & $4.5 \mathrm{a}$ & $2.3 \mathrm{~b}$ & $5.0 \mathrm{a}$ & $4.6 \mathrm{a}$ & $1.6 \mathrm{~b}$ & $602 \mathrm{a}$ & $677 \mathrm{a}$ & $288 \mathrm{~b}$ & $811 \mathrm{a}$ & $764 \mathrm{a}$ & $169 \mathrm{~b}$ \\
\hline Maria & $5.0 \mathrm{a}$ & $4.6 \mathrm{a}$ & $0.6 \mathrm{~b}$ & $5.0 \mathrm{a}$ & $3.4 \mathrm{~b}$ & $0.0 \mathrm{c}$ & $1177 \mathrm{a}$ & $1000 \mathrm{a}$ & - & $1511 \mathrm{a}$ & $512 \mathrm{~b}$ & - \\
\hline Mini & $5.0 \mathrm{a}$ & $4.1 \mathrm{~b}$ & $1.2 \mathrm{c}$ & $5.0 \mathrm{a}$ & $3.8 \mathrm{~b}$ & $0.0 \mathrm{c}$ & $550 \mathrm{a}$ & $575 \mathrm{a}$ & $193 \mathrm{~b}$ & $700 \mathrm{a}$ & $417 \mathrm{~b}$ & - \\
\hline
\end{tabular}

${ }^{\mathrm{z}}$ Means with same letters within a row and harvest are not significantly different among treatments by Tukey's honestly significant difference multiple comparison or between treatments by Student's $t$ test at $P<0.05$.

${ }^{\mathrm{y}}$ Data not collected because of dead plants.

Table 2. Shoot dry weight (DW) and relative chlorophyll content [soil plant analysis development (SPAD)] of eight barberry cultivars irrigated with nutrient solution [electrical conductivity $(E C)=1.2 \mathrm{dS} \cdot \mathrm{m}^{-1}$; control] or saline solution $\left[\mathrm{EC}=5.0 \mathrm{dS} \cdot \mathrm{m}^{-1}\right.$ (EC 5) or $10.0 \mathrm{dS} \cdot \mathrm{m}^{-1}$ (EC 10)] in the greenhouse. Plants were harvested after the fourth (first harvest) and eighth treatment (second harvest).

\begin{tabular}{|c|c|c|c|c|c|c|c|c|c|c|c|c|}
\hline \multirow{2}{*}{ Cultivars } & \multicolumn{6}{|c|}{ Shoot DW (g) } & \multicolumn{6}{|c|}{ SPAD } \\
\hline & \multicolumn{3}{|c|}{$\begin{array}{r}\text { First harvest } \\
\end{array}$} & \multicolumn{3}{|c|}{ Second harvest } & \multicolumn{3}{|c|}{ First harvest } & \multicolumn{3}{|c|}{ Second harvest } \\
\hline$\overline{\text { Celeste }}$ & $7.5 \mathrm{a}^{\mathrm{z}}$ & $5.1 \mathrm{~b}$ & $4.1 \mathrm{~b}$ & $15.0 \mathrm{a}$ & $7.9 \mathrm{~b}$ & $3.8 \mathrm{~b}$ & $24.0 \mathrm{a}$ & $19.3 \mathrm{~b}$ & $18.7 \mathrm{~b}$ & $30.1 \mathrm{a}$ & $27.1 \mathrm{a}$ & - \\
\hline Helmond Pillar & $5.3 \mathrm{a}$ & $5.1 \mathrm{a}$ & $3.9 \mathrm{a}$ & $9.7 \mathrm{a}$ & $5.2 \mathrm{~b}$ & $-^{y}$ & $42.1 \mathrm{ab}$ & $42.5 \mathrm{a}$ & $36.1 \mathrm{~b}$ & $45.8 \mathrm{a}$ & $29.5 \mathrm{~b}$ & - \\
\hline Kasia & $5.3 \mathrm{ab}$ & $6.2 \mathrm{a}$ & $3.8 \mathrm{~b}$ & $10.6 \mathrm{a}$ & $9.3 \mathrm{a}$ & $4.8 \mathrm{~b}$ & $17.1 \mathrm{a}$ & $20.6 \mathrm{a}$ & $18.2 \mathrm{a}$ & $26.1 \mathrm{a}$ & $18.2 \mathrm{~b}$ & $14.6 \mathrm{~b}$ \\
\hline Maria & $10.8 \mathrm{a}$ & $8.4 \mathrm{~b}$ & $5.3 \mathrm{c}$ & $21.3 \mathrm{a}$ & $10.6 \mathrm{~b}$ & - & $16.3 \mathrm{a}$ & $13.1 \mathrm{~b}$ & $8.8 \mathrm{c}$ & $22.8 \mathrm{a}$ & $12.3 \mathrm{~b}$ & - \\
\hline Mini & $7.6 \mathrm{a}$ & $7.2 \mathrm{a}$ & $4.6 \mathrm{~b}$ & $14.0 \mathrm{a}$ & $11.9 \mathrm{a}$ & - & $47.5 \mathrm{a}$ & $43.7 \mathrm{a}$ & $32.6 \mathrm{~b}$ & $51.7 \mathrm{a}$ & $31.8 \mathrm{~b}$ & - \\
\hline
\end{tabular}

${ }^{\mathrm{z}}$ Means with same letters within a row and harvest are not significantly different among treatments by Tukey's honestly significant difference multiple comparison or between treatments by Student's $t$ test at $P<0.05$.

${ }^{\mathrm{y}}$ Data not collected because of dead plants.

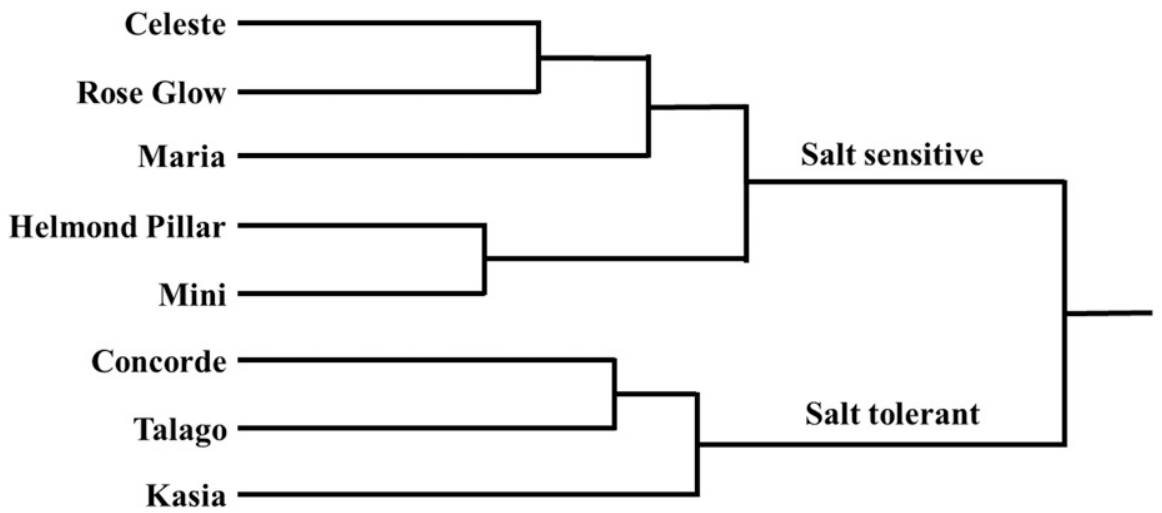

Fig. 2. Cluster analysis of the salt tolerance of eight barberry cultivars. The relative leaf area, relative shoot dry weight, relative soil plant analysis development (SPAD) reading, and visual score of barberry plants irrigated with saline solution at an electrical conductivity (EC) of $5.0 \mathrm{dS} \cdot \mathrm{m}^{-1}$ (EC 5) and 10.0 $\mathrm{dS} \cdot \mathrm{m}^{-1}$ (EC 10) were used as salt tolerance indices for hierarchical cluster analysis. The dendrogram was obtained based on the Ward's linkage method and squared Euclidean distance on the means of the salt tolerance indices for the aforementioned four multivariate parameters at both harvests. The relative leaf area and SPAD data in EC 10 were excluded in the cluster analysis because of incomplete data set resulting from dead plants.

confirmed using a hierarchical cluster analysis with multivariate parameters including visual score, relative leaf area, relative shoot DW, and relative SPAD in both EC 5 and EC 10 treatments. The dendrogram shows two distinguishable clusters (Fig. 2). The first cluster of 'Concorde', 'Kasia', and 'Talago' was considered salt-tolerant cultivars, whereas the second cluster of 'Celeste', 'Helmond Pillar', 'Maria', 'Mini', and 'Rose Glow' was saltsensitive cultivars.
Performance index. Performance index was affected by elevated salinity with variations among cultivars (Table 3 ). At the first harvest, a reduced PI was observed on all barberry cultivars in EC 5 and EC 10 in the morning except for 'Helmond Pillar', 'Kasia', and 'Talago' in EC 5, and 'Talago' in EC 10. In the afternoon, the PI of 'Concorde', 'Maria', and 'Talago' in EC 5 was reduced, but this was not the case for other cultivars. In addition, all barberry cultivars in
EC 10 had reduced PI. At the second harvest, EC 5 decreased the PI of 'Celeste', 'Helmond Pillar', 'Maria', 'Mini', and 'Rose Glow' measured both in the morning and afternoon. No significant difference of PI was observed between morning and afternoon $(P>0.05)$.

Performance index reflects the functionality of both photosystems I and II and is a sensitive indicator of plant vitality (Strasser et al., 2000, 2004). Our results agreed with a previous report that PI was shown to express only small diurnal changes (Živčák et al., 2014). Performance index has been reported to be sensitive to water stress reflecting different drought tolerance (Lepeduš et al., 2012; Živčák et al., 2008) and N deficiency (Živčák et al., 2014). In our study, PI was also responsive to salinity stress and could be a reliable and useful parameter to evaluate the salt damage of barberry cultivars.

Mineral analysis. Salt solution prepared with $\mathrm{NaCl}$ and $\mathrm{CaCl}_{2}$ increased the concentration of $\mathrm{Na}$ and $\mathrm{Ca}$ in barberry leaves (Table 4). Treatment EC 5 increased the $\mathrm{Na}$ concentration of all barberry cultivars. The averaged $\mathrm{Na}$ concentration of all barberry cultivars in EC 5 was 34 times higher than those in control. Treatment EC 10 further increased the $\mathrm{Na}$ concentration of all barberry cultivars up to 87 times higher than those in control. The highest Na concentration (17.4 $\mathrm{mg} \cdot \mathrm{g}^{-1} \mathrm{DW}$ ) was found in 'Maria' in EC 10. Compared with control, leaf Ca concentration of 'Celeste', 'Concorde', and 'Maria' in EC 5 increased by $47 \%, 34 \%$, and $78 \%$, 
Table 3. Performance index of eight barberry cultivars irrigated with nutrient solution [electrical conductivity $\left.(\mathrm{EC})=1.2 \mathrm{dS} \cdot \mathrm{m}^{-1} ; \mathrm{control}\right]$ or saline solution $[\mathrm{EC}=$ $5.0 \mathrm{dS} \cdot \mathrm{m}^{-1}$ (EC 5) or $10.0 \mathrm{dS} \cdot \mathrm{m}^{-1}$ (EC 10)] in the greenhouse. Data were collected after the fourth treatment (first harvest) and the eighth treatment (second harvest).

\begin{tabular}{|c|c|c|c|c|c|c|c|c|c|c|c|c|}
\hline \multirow{2}{*}{ Cultivars } & \multicolumn{6}{|c|}{ First harvest } & \multicolumn{6}{|c|}{ Second harvest } \\
\hline & \multicolumn{3}{|c|}{$\mathrm{AM}$} & \multicolumn{3}{|c|}{ PM } & \multicolumn{3}{|c|}{ AM } & \multicolumn{3}{|c|}{ PM } \\
\hline$\overline{\text { Celeste }}$ & $11.3 \mathrm{a}^{\mathrm{z}}$ & $7.4 \mathrm{~b}$ & $3.6 \mathrm{c}$ & $9.8 \mathrm{a}$ & $6.6 \mathrm{ab}$ & $3.6 \mathrm{~b}$ & $11.3 \mathrm{a}$ & $4.6 \mathrm{~b}$ & $4.4 \mathrm{~b}$ & $11.9 \mathrm{a}$ & $3.3 \mathrm{~b}$ & - \\
\hline Helmond Pillar & $7.9 \mathrm{a}$ & $5.3 \mathrm{ab}$ & $3.5 \mathrm{~b}$ & $6.2 \mathrm{a}$ & $6.0 \mathrm{a}$ & $2.2 \mathrm{~b}$ & $8.3 \mathrm{a}$ & $2.6 \mathrm{~b}$ & - & $9.9 \mathrm{a}$ & $4.5 \mathrm{~b}$ & - \\
\hline Kasia & $9.1 \mathrm{a}$ & $9.3 \mathrm{a}$ & $2.9 \mathrm{~b}$ & $11.3 \mathrm{a}$ & $8.9 \mathrm{ab}$ & $4.0 \mathrm{~b}$ & $7.5 \mathrm{a}$ & $4.7 \mathrm{a}$ & $6.7 \mathrm{a}$ & $4.6 \mathrm{a}$ & $6.3 \mathrm{a}$ & $3.0 \mathrm{~b}$ \\
\hline Maria & $9.8 \mathrm{a}$ & $6.0 \mathrm{~b}$ & $1.7 \mathrm{c}$ & $9.0 \mathrm{a}$ & $6.4 \mathrm{~b}$ & $1.2 \mathrm{c}$ & $8.3 \mathrm{a}$ & $5.1 \mathrm{~b}$ & - & $6.8 \mathrm{a}$ & $3.2 \mathrm{~b}$ & - \\
\hline Mini & $8.1 \mathrm{a}$ & $4.8 \mathrm{~b}$ & $0.9 \mathrm{c}$ & $6.9 \mathrm{a}$ & $4.5 \mathrm{ab}$ & $2.3 \mathrm{~b}$ & $7.5 \mathrm{a}$ & $4.4 \mathrm{~b}$ & - & $6.9 \mathrm{a}$ & $2.4 \mathrm{~b}$ & - \\
\hline
\end{tabular}

${ }^{\mathrm{z}}$ Means with same lowercase letters within a row and time are not significantly different among treatments by Tukey's honestly significant difference multiple comparison at $P<0.05$.

${ }^{\mathrm{y}}$ Data not collected because of dead plants.

Table 4. Foliar $\mathrm{Na}, \mathrm{Cl}, \mathrm{K}$, and $\mathrm{Ca}$ concentrations of barberry cultivars irrigated with nutrient solution [electrical conductivity $(\mathrm{EC})=1.2 \mathrm{dS} \cdot \mathrm{m}^{-1}$; control] or saline solution $\left[\mathrm{EC}=5.0 \mathrm{dS} \cdot \mathrm{m}^{-1}(\mathrm{EC} 5)\right.$ or 10.0 $\mathrm{dS} \cdot \mathrm{m}^{-1}$ (EC 10)] in the greenhouse. Plants at the first harvest were used for mineral analysis.

\begin{tabular}{|c|c|c|c|c|c|}
\hline \multirow[b]{2}{*}{ Cultivars } & \multirow[b]{2}{*}{ Treatment } & \multicolumn{4}{|c|}{ Mineral concn. (mg. $\mathrm{g}^{-1}$ dry weight) } \\
\hline & & $\mathrm{Na}$ & $\mathrm{Cl}$ & $\mathrm{Ca}$ & $\mathrm{K}$ \\
\hline \multirow[t]{3}{*}{$\overline{\text { Celeste }}$} & Control & $0.1 \mathrm{c}^{\mathrm{z}}$ & $0.8 \mathrm{c}$ & $7.9 \mathrm{c}$ & $15.6 \mathrm{~b}$ \\
\hline & EC 5 & $4.3 \mathrm{~b}$ & $22.2 \mathrm{~b}$ & $11.6 \mathrm{~b}$ & $18.0 \mathrm{ab}$ \\
\hline & EC 10 & $11.8 \mathrm{a}$ & $50.4 \mathrm{a}$ & $16.8 \mathrm{a}$ & $20.8 \mathrm{a}$ \\
\hline \multirow[t]{3}{*}{ Concorde } & Control & $0.1 \mathrm{c}$ & $0.6 \mathrm{c}$ & $7.5 \mathrm{c}$ & $17.9 \mathrm{a}$ \\
\hline & EC 5 & $2.6 \mathrm{~b}$ & $9.6 \mathrm{~b}$ & $10.0 \mathrm{~b}$ & $15.8 \mathrm{~b}$ \\
\hline & EC 10 & $6.7 \mathrm{a}$ & $22.2 \mathrm{a}$ & $12.6 \mathrm{a}$ & $16.5 \mathrm{~b}$ \\
\hline \multirow[t]{3}{*}{ Helmond Pillar } & Control & $0.3 \mathrm{c}$ & $0.5 \mathrm{c}$ & $8.3 \mathrm{~b}$ & $16.3 \mathrm{ab}$ \\
\hline & EC 5 & $6.6 \mathrm{~b}$ & $18.3 \mathrm{~b}$ & $11.0 \mathrm{ab}$ & $14.2 \mathrm{~b}$ \\
\hline & EC 10 & $14.1 \mathrm{a}$ & $40.0 \mathrm{a}$ & $15.0 \mathrm{a}$ & $17.1 \mathrm{a}$ \\
\hline \multirow[t]{3}{*}{ Kasia } & Control & $0.2 \mathrm{c}$ & $0.8 \mathrm{c}$ & $7.4 \mathrm{~b}$ & $19.6 \mathrm{a}$ \\
\hline & EC 5 & $4.8 \mathrm{~b}$ & $15.4 \mathrm{~b}$ & $10.9 \mathrm{~b}$ & $14.9 \mathrm{~b}$ \\
\hline & EC 10 & $15.3 \mathrm{a}$ & $54.8 \mathrm{a}$ & $16.6 \mathrm{a}$ & $20.1 \mathrm{a}$ \\
\hline \multirow[t]{3}{*}{ Maria } & Control & $0.1 \mathrm{c}$ & $0.7 \mathrm{c}$ & $10.2 \mathrm{c}$ & $19.8 \mathrm{~b}$ \\
\hline & EC 5 & $6.6 \mathrm{~b}$ & $44.8 \mathrm{~b}$ & $18.1 \mathrm{~b}$ & $26.6 \mathrm{a}$ \\
\hline & EC 10 & $17.4 \mathrm{a}$ & $68.1 \mathrm{a}$ & $23.4 \mathrm{a}$ & $26.4 \mathrm{a}$ \\
\hline \multirow[t]{3}{*}{ Mini } & Control & $0.2 \mathrm{c}$ & $0.3 \mathrm{c}$ & $9.2 \mathrm{~b}$ & $17.4 \mathrm{ab}$ \\
\hline & EC 5 & $4.4 \mathrm{~b}$ & $14.3 \mathrm{~b}$ & $12.1 \mathrm{~b}$ & $15.7 \mathrm{~b}$ \\
\hline & EC 10 & $10.3 \mathrm{a}$ & $34.9 \mathrm{a}$ & $17.8 \mathrm{a}$ & $19.1 \mathrm{a}$ \\
\hline \multirow[t]{3}{*}{ Rose Glow } & Control & $0.1 \mathrm{c}$ & $0.5 \mathrm{c}$ & $10.9 \mathrm{~b}$ & $18.7 \mathrm{~b}$ \\
\hline & EC 5 & $4.5 \mathrm{~b}$ & $28.3 \mathrm{~b}$ & $13.3 \mathrm{~b}$ & $21.1 \mathrm{ab}$ \\
\hline & EC 10 & $10.7 \mathrm{a}$ & $46.4 \mathrm{a}$ & $18.1 \mathrm{a}$ & $21.9 \mathrm{a}$ \\
\hline \multirow[t]{3}{*}{ Talago } & Control & $0.2 \mathrm{c}$ & $1.0 \mathrm{c}$ & $9.0 \mathrm{~b}$ & $16.2 \mathrm{a}$ \\
\hline & EC 5 & $4.8 \mathrm{~b}$ & $18.0 \mathrm{~b}$ & $10.9 \mathrm{~b}$ & $14.2 \mathrm{a}$ \\
\hline & EC 10 & $10.3 \mathrm{a}$ & $34.2 \mathrm{a}$ & $15.2 \mathrm{a}$ & $17.2 \mathrm{a}$ \\
\hline
\end{tabular}

$\overline{{ }^{\mathrm{z}} \text { For each cultivar, means with same lowercase letters within a column are not significantly different }}$ among treatments by Tukey's honestly significant difference multiple comparison at $P<0.05$.

respectively, whereas those in EC 10 increased by $112 \%, 68 \%$, and $130 \%$, respectively (Table 4). Treatment EC 5 did not increase the leaf $\mathrm{Ca}$ concentration of 'Helmond Pillar', 'Kasia', 'Mini', 'Rose Glow', and 'Talago', but EC 10 increased the leaf $\mathrm{Ca}$ concentration by $81 \%, 124 \%, 94 \%, 66 \%$, and $68 \%$, respectively. Salt treatment also increased leaf $\mathrm{Cl}$ concentrations (Table 4). The leaf $\mathrm{Cl}$ concentration of all barberry cultivars in EC 5 was 14-60 times higher than that of their respective control, whereas those in EC 10 had 34-106 times more in leaf $\mathrm{Cl}$ concentrations. The highest $\mathrm{Cl}$ concentration (68.1 $\mathrm{mg} \cdot \mathrm{g}^{-1} \mathrm{DW}$ ) was found in 'Maria' barberry in EC 10.

Marosz (2012) reported that leaf $\mathrm{Na}$ content of $B$. thunbergii 'Atropurpurea' seedlings irrigated with tap water containing 3.3 $\mathrm{g} \cdot \mathrm{L}^{-1}(56.4 \mathrm{~mm}) \mathrm{NaCl}$ for eight times at 7-day intervals increased 15 times compared with that containing $0 \mathrm{~mm} \mathrm{NaCl}$, but the leaf $\mathrm{Ca}$ concentration did not change; however, when the plants were irrigated with tap water containing $10.5 \mathrm{~g} \cdot \mathrm{L}^{-1} \quad \mathrm{Na}_{2} \mathrm{CO}_{3}(100 \mathrm{~mm})$, the leaf $\mathrm{Na}$ increased 17.5 times and $\mathrm{Ca}$ concentration decreased by $24 \%$. Both studies consistently showed that barberry plants preferentially uptake $\mathrm{Na}$ instead of $\mathrm{Ca}$ when they were grown at elevated salinity conditions. High concentrations of $\mathrm{Na}, \mathrm{Cl}$, or both accumulated in leaf tissue may damage the chloroplasts and thus inhibit photosynthesis (Taiz and Zeiger, 2015). Excessive $\mathrm{Na}$ and $\mathrm{Cl}$ uptake also competes with the uptake of other nutrient ions such as $\mathrm{K}$ or nitrogen $(\mathrm{N})$, resulting in nutritional disorders and reduced plant quality (Grattan and Grieve, 1999).

Potassium plays an important role in regulation of the $\psi_{\mathrm{S}}$ of plant cells and also activates many enzymes involved in respiration and photosynthesis (Taiz and Zeiger, 2015). High accumulation of Na might cause the reduction of $\mathrm{K}$ uptake (Hasegawa et al.,
2000). In our study, treatment EC 5 reduced the leaf $\mathrm{K}$ concentration of 'Concorde' and 'Kasia' barberry, and EC 10 further decreased the leaf $\mathrm{K}$ concentration of 'Concorde' barberry (Table 4). However, compared with control, no significant difference of leaf $\mathrm{K}$ content was observed in 'Helmond Pillar', 'Mini', and 'Talago' in both EC 5 and EC 10, 'Celeste' and 'Rose Glow' in EC 5, and 'Kasia' in EC 10. Similar results have been documented by Marosz (2012) showing that the leaf $\mathrm{K}$ content of $B$. thunbergii 'Atropurpurea' seedlings did not change when irrigated with tap water containing $3.3 \mathrm{~g} \cdot \mathrm{L}^{-1}(56.4 \mathrm{mM}) \mathrm{NaCl}$ or $6.0 \mathrm{~g} \cdot \mathrm{L}^{-1}$ $\mathrm{CaCl}_{2}(54.1 \mathrm{~mm})$. In addition, leaf $\mathrm{K}$ content of 'Maria' in both EC 5 and EC 10 and 'Celeste' and 'Rose Glow' in EC 10 increased with saline solution applied.

\section{Conclusions}

Among the eight barberry cultivars used in this study, Helmond Pillar, Maria, Mini, and Rose Glow barberry were relatively salt sensitive as evidenced by higher mortality, greater reduction in shoot DW, and more severe foliar salt damage. 'Concorde', 'Kasia', and 'Talago' barberry were more salt tolerant with less foliar salt damage and smaller reduction in shoot DW at elevated salinity. Salt tolerance of 'Celeste' barberry was slightly better than that of the clustered sensitive group. These results are valuable for growers and landscape professionals in plant selection for sites where low-quality water may be used for irrigation.

\section{Literature Cited}

Altland, J.E., J.C. Locke, and C.R. Krause. 2014. Influence of pine bark particle size and $\mathrm{pH}$ on cation exchange capacity. HortTechnology 24:554-559.

Beckerman, J. and B.R. Lerner. 2009. Salt damage in landscape plants. Purdue Univ. Coop. Ext. Serv. Bul. ID-412-W.

Cai, X., Y. Sun, T. Starman, C. Hall, and G. Niu. 2014. Response of 18 Earth-Kind ${ }^{\circledR}$ rose cultivars to salt stress. HortScience 49:544-549.

Cavins, T.J., B.E. Whipker, and W.C. Fonteno. 2008. Pourthru: A method for monitoring nutrition in the greenhouse. Acta Hort. 779:289-297.

Chalet Nursery. 2013. Salt tolerant plants. Chalet Nursery, Wilmette, IL. 
Costello, L.R., E.J. Perry, N.P. Matheny, J.M. Henry, and P.M. Geisel. 2003. Abiotic disorders of landscape plant: A diagnostic guide. Univ. California Agr. Natural Resources, Davis, CA. Pub. 3420.

Davis Landscape Architecture. 2017. Landscape architect's pages: Berberis thunbergii. Davis Landscape Architecture Ltd., London, UK. 30 Jan. 2017. <https://davisla.wordpress.com/2011/ 11/03/plant-of-the-week-berberis-thunbergii-2/>.

Dirr, M.A. 1998. Manual of woody landscape plants: Their identification, ornamental characteristics, culture, propagation and uses. 5th ed. Stipes Publishing L.L.C., Champaign, IL.

Gabriel, M., J.E. Altland, and J.S. Owen, Jr. 2009. The effect of physical and hydraulic properties of peatmoss and pumice on Douglas fir bark based soilless substrates. HortScience 44:874878.

Gavlak, R.G., D.A. Horneck, and R.O. Miller. 1994. Plant, soil, and water reference methods for the western region. Western Regional Ext. Publ. (WREP) 125.

Gilman, E.F. 2014. Berberis thunbergii japanese barberry. Univ. Florida/Inst. Food Agr. Sci. Ext. FPS66.

Glen, C., M. Martin, and D. Nash. 2004. Salt tolerant plants recommended for Pender County landscapes. North Carolina State Univ. and North Carolina A\&T State Univ. Coop. Ext. Urban Horticulture Leaflet 14.

Grattan, S.R. and C.M. Grieve. 1999. SalinityMineral nutrient relations in horticultural crops. Sci. Hort. 78:127-157.

Grieve, C.M. 2011. Review irrigation of floricultural and nursery crops with saline wastewaters. Isr. J. Plant Sci. 59:187-196.

Grieve, C., L. Wu, L. Rollins, and A. Harivandi. 2008. Tolerance by landscape plants of salinity and of specific ions, p. v1-v59. In: K. Tanji, S. Grattan, C. Grieve, A. Harivandi, L. Rollins, D. Shaw, B. Sheikh, L. Wu, and P. Suyama (eds.). A comprehensive literature review on salt management guide for landscape irrigation with recycled water in coastal southern California. University of CaliforniaDavis, Davis, CA.

Handreck, K. and N. Black. 2002. Growing media for ornamental plants and turf. 3rd ed. Univ. New South Wales Press Ltd., Sydney, Australia.

Harrison, M. 2009. Flowering shrubs and small trees for the south. Pineapple Press, Inc., Sarasota, FL.

Hasegawa, P.M., R.A. Bressan, J.K. Zhu, and H.J. Bohnert. 2000. Plant cellular and molecular responses to salinity. Annu. Rev. Plant Physiol. Plant Mol. Biol. 51:463-499.

Havlin, J.L. and P.N. Soltanpour. 1989. A nitric acid and plant digest method for use with inductively coupled plasma spectrometry. Commun. Soil Sci. Plant Anal. 14:969-980.

Isaac, R.A. and W.C. Johnson. 1975. Collaborative study of wet and dry ashing techniques for the elemental analysis of plant tissue by atomic absorption spectrophotometry. J. Assn. Off Anal. Chem. 58:436-440.

Jull, L.G. 2009. Winter salt injury and salt-tolerant landscape plants. Univ. Wisconsin Coop. Ext. A3877.

Lepeduš, H., I. Brkić, V. Cesar, V. Jurković, J. Antunović, A. Jambrović, J. Brkić, and D. Šimić. 2012. Chlorophyll fluorescence analysis of photosynthetic performance in seven maize inbred lines under water-limited conditions. Period. Biol. 114(1):73-76.

Marosz, A. 2012. Effect of green waste compost and mycorrhizal fungi on calcium, potassium, and sodium uptake of woody plants grown under salt stress. Water Air Soil Pollut. 223:787-800.

Monk, R.W. and H.H. Wiebe. 1961. Salt tolerance and protoplasmic salt hardiness of various woody and herbaceous ornamental plants. Plant Physiol. 36(4):478-482.

Niu, G. and R.I. Cabrera. 2010. Growth and physiological responses of landscape plants to saline water irrigation: A review. HortScience 45:1605-1609.

Niu, G. and D.S. Rodriguez. 2006. Relative salt tolerance of selected herbaceous perennials and groundcovers. Sci. Hort. 110:352-358.

Niu, G., D.S. Rodriguez, and C. McKenney. 2012a. Response of selected wildflower species to saline water irrigation. HortScience 47:1351-1355.

Niu, G., T. Starman, and D. Byrne. 2013. Responses of growth and mineral nutrition of garden roses to saline water irrigation. HortScience 48:756-764.

Niu, G., M. Wang, and D. Rodriguez. 2012b. Response of zinnia plants to saline water irrigation. HortScience 47:793-797.

Smith, M., K. Cross, M. Paden, and P. Laban. 2016. Spring-Managing groundwater sustainably. IUCN, Gland, Switzerland.

Strasser, R.J., A. Srivastava, and M. TsimilliMichael. 2000. The fluorescence transient as a tool to characterize and screen photosynthetic samples, p. 445-483. In: M. Yunus, U. Pathre, and P. Mohanty (eds.). Probing photosynthesis: Mechanisms, regulation and adaptation. Taylor and Francis, London, UK.
Strasser, R.J., M. Tsimilli-Michael, and A. Srivastava. 2004. Analysis of the fluorescence transient, p. 321-362. In: G.C. Papageorgiou and Govindjee (eds.). Chlorophyll fluorescence: A signature of photosynthesis. Advances in photosynthesis and respiration series. Springer, Dordrecht, The Netherlands.

Sun, Y., G. Niu, and J. Masabni. 2015a. Simulated sea water flooding reduces the growth of ten vegetables. HortScience 50:694-698.

Sun, Y., G. Niu, P. Osuna, G. Ganjegunte, D. Auld, L. Zhao, J.R. Peralta-Videa, and J.L. GardeaTorresdey. 2013. Seedling emergence, growth, and leaf mineral nutrition of Ricinus communis L. cultivars irrigated with saline solution. Ind. Crops Prod. 49:75-80.

Sun, Y., G. Niu, and C. Perez. 2015b. Relative salt tolerance of seven Texas Superstar ${ }^{\circledR}$ perennials. HortScience 50:1562-1566.

Taiz, L. and E. Zeiger. 2015. Plant physiology and development. 6th ed. Sinauer Assoc., Inc., Publ., Sunderland, MA.

U.S. Department of Agriculture. 2009. Census of horticultural specialties in 2009. 30 Jan. 2017. $<$ http://www.agcensus.usda.gov/Publications/ 2007/Online_Highlights/Census_of_Horticulture_ Specialties/hortic_1_023_023.pdf $>$.

Veatch-Blohm, M.E., D. Sawch, N. Elia, and D. Pinciotti. 2014. Salinity tolerance of three commonly planted Narcissus cultivars. HortScience 49:1158-1164.

Wahome, P.K., H.H. Jesch, and I. Grittner. 2001 Mechanisms of salt stress tolerance in two rose rootstocks: Rosa chinensis 'Major' and $R$. rubiginosa. Sci. Hort. 87:207-216.

Wikipedia, The Free Encyclopedia. 2017. Berberis thunbergii. Wikimedia Foundation, Inc., San Francisco, CA. 30 Jan. 2017. < https://en.wikipedia.org/ wiki/Berberis_thunbergii $>$.

Wright, R.D. 1986. The pour-through nutrient extraction procedure. HortScience 21:227-229.

Zeng, L., M.C. Shannon, and C.M. Grieve. 2002. Evaluation of salt tolerance in rice genotypes by multiples agronomic parameters. Euphytica 127:235-245.

Živčák, M., M. Brestič, K. Olšovská, and P. Slamka. 2008. Performance index as a sensitive indicator of water stress in Triticum aestivum L. Plant Soil Environ. 54(4):133-139.

Živčák, M., K. Olšovská, P. Slamka, J. Galambošová, V. Rataj, H.B. Shao, and M. Brestič. 2014. Application of chlorophyll fluorescence performance indices to assess the wheat photosynthetic functions influenced by nitrogen deficiency. Plant Soil Environ. 60(5):210-215. 